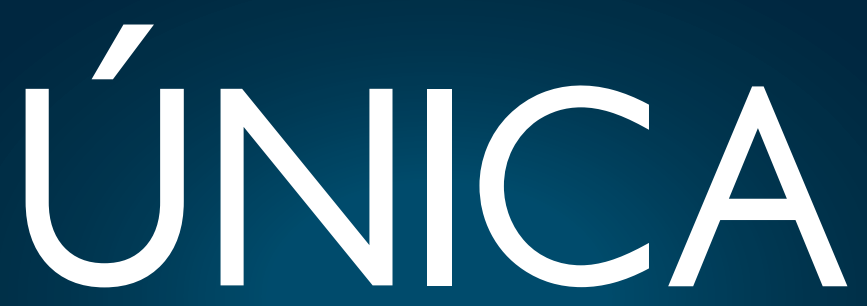

INSTITUCIÓN UNIVERSITARIA COLOMBO AMERICANA

Working Papers

\title{
KNITTING CITIZENSHIP COMPETENCIES WITH MOTHERS, A SYSTEMATIZATION OF EXPERIENCE
}

\section{- JASMIN ALFONSO -}

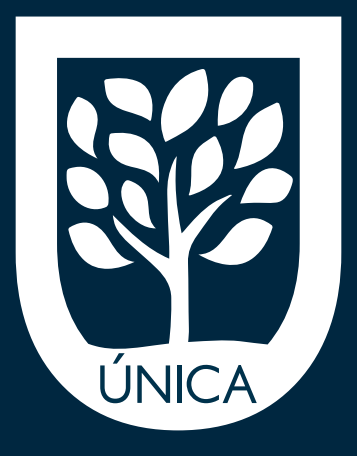

ww.unica.edu.co 
Facultad de Educación Programa de Licenciatura en Bilingüismo con Énfasis en Español e Inglés

Bogotá D.C. 2020

Reg. SNIES: 106242

Vigilada MinEducación

Working Paper - Resultado de Investigación

Grupo de Investigación Innovation on Bilingual Education - INNOBED

Categoría B Colciencias

Dirección de Investigaciones y Sostenibilidad

Calle 19 No. $2^{\text {a }}-49$, Piso 3 Centro Colombo Americano

Teléfono: 2811777 Ext. 1291

dir.investigaciones@unica.edu.co

www.unica.edu.co

DOI: https://doi.org/10.26817/paper.11

Prohibida la reproducción parcial o total de esta obra sin autorización de la Institución Universitaria Colombo Americana - ÚNICA 


\title{
KNITTING CITIZENSHIP COMPETENCIES WITH MOTHERS, A SYSTEMATIZATION OF EXPERIENCE
}

\author{
Institución Universitaria Colombo Americana - ÚNICA
}

Jasmin Alfonso

\begin{abstract}
This document is a systematization of the experience lived with a mothers' knitting group in a local community in Bogotá. It contains reflections on the introduction and application of some tools of Positive Discipline and Restorative Practices to help mothers build citizenship competencies such as assertiveness and empathy with their children. This is a retrospective systematization of experience that used observations during the knitting group meetings, reflective notes while planning content for the sessions, and semi structured interviews with mothers at the beginning and the end of the program. Results demonstrated that building community is a key starting point to develop assertiveness and empathy. Several elements from approaches of Positive Discipline and Restorative Practices are useful to foster citizenship competencies.
\end{abstract}

Key words: citizenship competencies, assertiveness, empathy, positive discipline, restorative practices, parenting, community building.

\section{Resumen}

Esta es una sistematización de experiencia del trabajo realizado con madres de familia pertenecientes a un grupo de tejido de una comunidad en Bogotá. Este documento presenta las reflexiones sobre el proceso de introducción y aplicación de algunas herramientas de disciplina positiva y prácticas restaurativas para ayudar a las madres a construir competencias ciudadanas como asertividad y empatía con sus hijos. Esta es una sistematización de experiencia retrospectiva que incluyó el uso de observaciones durante las reuniones del grupo de tejido, reflexiones durante la planeación de contenidos para las sesiones y entrevistas semiestructuradas con las madres al comienzo y al final del programa. Los resultados demostraron que la construcción de comunidad es un aspecto inicial clave para el desarrollo de la asertividad y la empatía. Varios elementos de disciplina positiva y prácticas restaurativas son útiles para fomentar competencias ciudadanas.

Palabras clave: competencias ciudadanas, asertividad, empatía, disciplina positiva, prácticas restaurativas, crianza, construcción de comunidad. 


\section{Introduction}

This research project about citizenship competencies originated during the researcher's participation in a knitting group at the community center in the Benjamin Herrera neighborhood in Bogotá. This place was also the scenario of an after-school program that was held at the same time. A community leader provided support to a few children in homework assignments in school subjects such as English, Language, and Mathematics. It came to the attention of the researcher the way children were treated during the after-school program (i.e., children being yelled at and lectured, sent to negative time out, asked to be sit and silent for long periods of time). A contradictory discourse was evidenced between actions of the adult in charge of the after-school program and what she intended to teach to the children in this program about citizenship competencies. Lectures about children not being respectful and how important it was to be respectful were given to the students who listened passively and obediently. Children were asked to make posters about the definition of a given value (e.g. respect, responsibility, honesty, empathy, etc.) and to recite the information to mothers in the knitting group who were pleased that children were learning values.

These events led to a proposal to the $\mathrm{BH}$ Community Action Committee about the creation of a vacation program to teach English and some basic citizenship competencies (i.e., empathy and assertiveness) to children. The proposal was accepted and included a few basic topics related to English, but most importantly, it contained activities in Spanish to foster empathy and assertiveness (telling stories, games, and hands-on activities) that were mainly adapted from the manual Educating for Peace (Ministry of Education, 2016). During the vacation program, it was evident that children were not used to listening, taking turns, and showing respect to each other. Nonetheless, the children were able to verbalize why it was important to be respectful, to listen to others' ideas, and to raise their hands to participate. Varied activities were applied to foster a more positive classroom atmosphere, however the children continuously argued, screamed at, and disrespected each other. The vacation program was abruptly cancelled by the leader of the community action committee due to the students' misbehavior. Students were lectured for not being respectful towards each other and the teacher in charge (the researcher) and were asked to apologize. The teacher-researcher realized that these children were not to blame for their misbehavior, and that work on teaching citizenship competencies could be more effective if done with mothers in the first place.

A review of the literature has called direct attention to a serious reality in the Colombian context. Vanstralen and López (2018) sustained that while the 
responsibility of the family in the teaching of citizenship is usually highlighted, all the efforts from the state are mainly focused on the teachers, with little emphasis on students' families. Likewise, Castellanos and Chaparro (2016) pointed out the challenging reality of many households where adults are unaware of citizenship competencies and, therefore, are unable to practice them. These circumstances motivated the researcher to systematize the experience lived with the mothers in the knitting group so that possible future workshops could be better planned and executed in the same community or elsewhere.

In this context, designing workshops that integrated restorative practices and positive discipline tools seemed useful to address the development of citizenship competencies with the mothers.

\section{Citizenship competencies}

The Colombian Ministry of Education (2016) defines citizenship competencies as the knowledge and cognitive, emotional, and communicative abilities that are necessary for an individual to be able to act constructively in a democratic society. This means, that such competencies help, young people especially, to relate to each other respectfully and enable them to solve everyday conflict. The standards of citizenship skills stated by the Ministry, establish what students should know and know how to do according to their developmental level so that they practice such abilities at home, at school and in other contexts.

The program emphasizes four types of competencies: emotional, cognitive, communicative and integrative. The emotional competence refers to the ability to respond constructively to our own emotions (e.g. managing anger not to harm others) and others' emotions (e.g. empathy). Identifying our own emotions is an essential step in order to handle them. Being aware of physical signs associated with diverse emotions, being able to name the emotions we are feeling and their intensity, and distinguishing the situations that trigger given emotions, are key factors to manage them appropriately (Ruiz and Chaux, 2005). The second emotional competence previously mentioned refers to the ability to respond empathically to the other person's emotions. Empathy is the ability to place ourselves in somebody's shoes and try to feel something similar or compatible with what the other person is feeling. An empathetic individual is more likely to help others, avoids hurting others physically or psychologically and looks for reconciliation. All in all, empathy is fundamental for human coexistence and respect for other living beings.

The cognitive competencies are the mental processes that facilitate interactions in society (e.g. the ability to place ourselves mentally in somebody's position). The communicative competencies relate to the ability to establish constructive communication with other individuals. Apart from active listening, assertiveness is an essential element when communicating with others. Assertiveness is the ability to express needs, interests and ideas clearly without hurting other people's feelings. Assertiveness is necessary to express disagreement or respond to an offensive comment or action in a way that is not aggressive. It does not only raise awareness 
of one's rights but also others' rights. (Ruiz and Chaux, 2005). Lastly, the integrative competencies assemble the emotional, cognitive and communicative competences.

While the Ministry of Education provides a comprehensive definition of Citizenship competencies, Villarini (cited in Rodriguez, Ruiz and Guerra, 2007) discusses also the meaning of competent. Being competent means that the individual possesses declarative knowledge (i.e., information and concepts), that is, the individual knows what she does and why and knows the object of study. Being competent implies also being able to execute an action or having procedural knowledge and the intellectual and psychomotor abilities to execute an action. Lastly, being competent implies an attitude (attitudinal knowledge) of willingness to use declarative and procedural knowledge and doing it in a way that is correct. Likewise, Perrenoud (cited in Rodriguez, Ruiz and Guerra, 2007) proposes that the concept of competence includes four types of knowledge: schemes of thought (complex knowledge that guides action), know, know-how and attitudes.

There is not much success in possessing only declarative knowledge about assertiveness (communicative competence) and empathy (emotional competence), it is necessary for adults to address real conflictive experiences with young learners to help them develop procedural knowledge. Thus, some elements of positive discipline and restorative practices can help bridge the existing gap between knowledge of such competencies and their actual application. In order to achieve this transformation, assertiveness and empathy can be modeled by parents by recognizing and making demands according to their children's cognitive development level, by replacing punishment for logical consequences and by using misbehavior episodes to foster reflection with affective questions and asking statements.

\section{Positive Discipline}

A steppingstone to building citizenship competencies in children was exploring mothers' beliefs and practices in this regard and providing them with alternative resources that could nurture their ability to teach the competencies. To this end, Positive Discipline (PD) and Restorative Practices (RP) tools set the theoretical ground to guide the work with the mothers in the knitting group because they are both based on the premise that young people can learn to become responsible, respectful, and contributing members of the community, family, and school if they are properly guided. Positive discipline is a philosophy used in schools and in parenting that is based on encouragement, empowerment, and mutual respect. It teaches social and life skills (respect, concern for others, problem solving, cooperation, contribution), and also teaches adults to employ kindness and firmness at the same time when teaching them. Nelsen, Lott, and Glenn (2013) emphasized essential factors that tools and concepts of positive discipline include:

- Mutual respect. Adults model firmness by respecting themselves and the needs of the situation, and kindness by respecting the needs of the child. 
- Identifying the belief behind the behavior. Effective discipline recognizes the reasons kids do what they do, and works to change those beliefs, rather than merely attempting to change behavior.

- Effective communication and problem-solving skills.

- Discipline that teaches and it is neither permissive nor punitive.

- Focusing on solutions instead of punishment.

- Encouragement instead of praise. Encouragement notices effort and improvement, not just success, and builds long-term self-esteem and empowerment.

\section{Restorative Practices}

They are an emerging social science that studies how to strengthen relationships between individuals as well as social connections within communities (International Institute for Restorative Practice IIRP, 2016). "These practices have been applied in justice systems, families, workplaces and neighborhoods, as well as in schools" (Costello, Wachtel \& Wachtel, 2009, p. 7). While the Restorative Practices handbook written by the same authors, offers several tools directly connected to building restorative classrooms, they also seem appropriate to address issues within the families.

In the Restorative Practices, affective statements are a crucial tool for people to express themselves. They are just another way of saying 'express your feelings', they encourage positive relationships as they allow individuals to demonstrate feelings, instead of making them appear as mere authority figures. In restorative practices, affective statements are useful to express both pleasant and unpleasant feelings. For instance, to acknowledge a child's hard work and collaboration, an adult can say, "I was really happy this morning when you got ready for school on time". Similarly, when being concerned about a child's behavior, the statement needs to be specific and sincere: "I'm frustrated that you aren't listening to me". Affective statements are alternative ways to the usual phrases "don't do that", "stop that", and "that's not good" that adults tell children.

Apart from affective statements, restorative practice tools include the use of affective or restorative questions to address behavior problems. These questions help to elicit what a child is feeling or thinking about a problematic situation they have participated in. The questions can be asked to help the person reflect and better understand the impact of their behavior, and how it has an impact on themselves and others. Some common affective questions are: What happened? As contrary to the usual Why did you do that? which is a meaningless question for young people do not usually know why they did something wrong. Other helpful questions include: What impact has this situation had on you and others? Who has been affected by your behavior? How do you think they feel? How do you feel now? What do you think needs to happen to make things right? This restorative approach assumes that people are able to 
achieve better behavior and that they can suggest their own reparative actions, it also points out the ineffectiveness of punishment to deal with inappropriate behavior. Punishment works only superficially, primarily when the misbehaving students are in view of those in authority, "punishment does not create empathy in students and does not encourage them to internalize a commitment to behave properly, so as soon as they are out of sight the inappropriate behavior surfaces again" (Costello, Wachtel \& Wachtel, 2009, p. 62).

\section{Community Circles}

The Circle is a symbol of community that has existed from ancestral times when human beings' earliest discussions took place in circles around the fire. Circles are one of the most distinctive and flexible tools of Restorative Practices whose main purpose is building community and supporting the kinds of honest, authentic dialogue that is necessary to effectively respond to challenging behavior and circumstances (Clifford, 2015). Circles are a powerful tool to build community, as Costello, Wachtel and Wachtel (2010) clearly explained:

In circles we face each other and speak respectfully, one person at a time, diminishing the feeling of disconnectedness that permeates our modern world and restoring the sense of belonging that constitutes a healthy human community. We may find that this ancient form of social discourse helps us address our greatest challenges (p.113).

When we sit in a circle, we experience connection and a stronger sense of community. We feel connected to other people when we sense that they see us, know us, and care about us. Community circles then are about being seen, being heard, being known, and developing affection (Clifford, 2015). According to Costello, and Wachtel and Wachtel (2010), because of the structure of circles, they convey certain values:

Equality: All participants in the circle have equal seating which means an absence of hierarchical interaction.

Safety and trust: Everyone in the circle is visible, nothing and nobody is hidden.

Facilitation: In the circle the leader facilitates rather than lectures.

Ownership: Collectively, the participants feel their circle is theirs.

Connections: These are built as each other's responses are heard.

\section{Methodology}

\section{Setting and Participants}


This project was carried out from July 2018 to December 2019 with some mothers belonging to a knitting group at the Benjamin Herrera Community $(\mathrm{BHC})$ located in the locality Barrios Unidos in Bogota in the northwest of the city. This is a commercial area characterized by the large number of garages. This district is mostly inhabited by low middle-class residents, but most of the population is made up of people who commute every day from other parts of the city as they are workers at the local auto

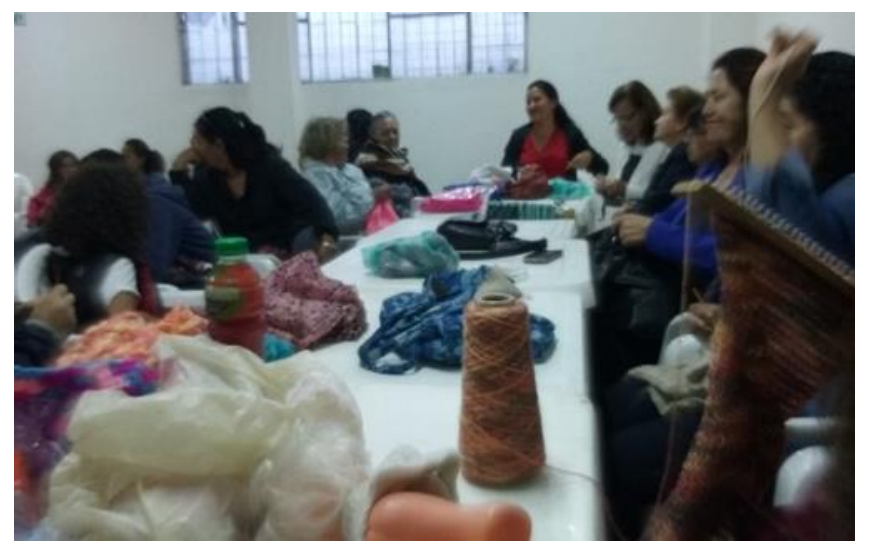
parts, motorbike shops and repair shops.

Although this experience consisted of two main phases developed in the same community, the first one teaching children in the vacation program and the second working with the mothers of the knitting group, this is a partial systematization as it only involves one part of the experience, in this case the work done with the mothers. Initially, the knitting group was composed of 4 mothers of school-aged children, 2 grandmothers and 5 mothers of adolescents. However, a good number of them only attended the weekly meetings sporadically due to family or work issues. Some were working single mothers or housewives taking care of children or grandparents.

\section{Research design}

This study is a systematization of experience, a type of qualitative research approach, aimed at improving practice based on a critical reflection and interpretation of lessons learned from that practice. In different fields generally deals with the organization of information and data. However, in popular education and social processes, it refers not only to data and information that is gathered and organized, but also to a critical view that fosters learning from our experiences. This is why it is called systematization of experience rather than just systematization. Jara (1994) pointed out that experiences are complex processes in which objective and subjective factors converge: contextual factors or historic moments in which they happen; particular situations that make them possible; intentional actions with specific goals; reactions generated from such actions; expected and unexpected results; perceptions, interpretations, intuitions and emotions of the people who intervene; and relationships that are established among the people who live the experience.

A good number of scholars (Martinic, 1987; Cadena, 1985; Cifuentes, 1999; Barnechean \& Morgan 2007; Zuniga, 1995 (as cited in Jara 2018); and De Souza, 2008) have conceptualized what a systematization of experiences is, each of them making particular emphasis on certain elements, nonetheless these views coincide in considering it as a process of individual and collective reflection that derives from actual practice, a reconstruction of experience, a critical view of the experience 
lived, and a source of new knowledge (Jara, 2018). An important element of this type of qualitative research is the critical reflection that a given experience brings about. Ocampo and Berdegué (2000), (as cited in UNESCO, 2016) explained this process as an opportunity for the direct participants to make a stop and think about what they did, analyze why they did it, why they did it in a certain way and not differently, what the results were, what for and who benefited from the results. Similarly, UNESCO (2016) regards the systematization of experience "as a valuable resource to see oneself, to be critical to recognize advances and keep learning. It integrates reflection about one's own experience and is an opportunity to grow professionally" (p. 12). The lessons learned in this process can help the same people improve their future practice or can help other people and teams in other places and moments to plan and execute their own projects.

\section{Research questions}

This systematization of experience was guided by the following main question:

- How to develop and implement workshops using Positive Discipline and Restorative Practices elements to help mothers build citizenship competencies (assertiveness and empathy) with their children?

Some secondary questions were:

- What tools from Positive Discipline and Restorative Practices could be used to help mothers develop assertiveness and empathy with their children?

- How do tools from Positive Discipline and Restorative Practices can be integrated into the teaching and learning of assertiveness and empathy with children?

- What elements for workshop design are required to help mothers build empathy and assertiveness with their children?

\section{Data Collection Tools}

The present research study involved collecting data from observations, reflections and qualitative interviews. Participant observation opportunities emerged as the researcher participated in the knitting activities and built rapport with the members of the group. "Participant observation is the process of establishing rapport within a community and learning to act in such a way as to blend into the community so that its members will act naturally, then removing oneself from the setting or community to immerse oneself in the data to understand what is going on and be able to write about it" (Bernard, 1994, as cited in Kawulich, 2005, p. 3). The observations entailed a holistic description of events, behaviors, and ideas of the mothers belonging to the group. These descriptive notes were kept on the left side of a format, and a subsequent reflection about that data, on the right, gave way to insights and clues on what was going on during the meetings. Reflections were written by the researcher as the workshops were being planned. 
Finally, one-on-one interviews were carried out with the mothers at the beginning and end of the program. At the beginning stage, open ended questions were asked to explore and analyze their beliefs and teaching practices of citizenship competencies at home. By the end of the experience, the mothers were interviewed again to enquire about possible learning gains from the workshops and their experience learning with the other mothers. The data collected through each openended question answered by the participants was typed into a table for analysis. This research looked for overlapping themes in the open-ended data to analyze the openended responses provided by the participants (Creswell, 2012). Each participant was given a pseudonym to protect their identity.

\section{Workshop Design and Implementation}

The work with mothers in the $\mathrm{BHC}$ was initiated through weekly meetings that lasted two hours, thirteen workshop sessions were held in total. The next topics were selected to design workshops as they seemed to help building citizenship competencies from a more participative and positive standpoint as opposed to traditional punitive approaches to discipline.

\section{Table 1}

Content addressed during the knitting group meetings

Topic Description

Positive Discipline

Parenting: short-term, long-term goals

Cognitive development of children

Telling statements, asking statements

Punishment, positive discipline

Restorative Practices

Affective statements

Affective questions

Community Circles

Based on the most common difficulties children in the vacation course demonstrated in terms of interaction with peers and adults, the citizenship competencies selected as the focus of the work with mothers were assertiveness (communicative competence) and empathy (emotional competence). These two areas were 
addressed following the principles established by Chaux, 2008 (as cited in Castillo, 2018). Although his research about citizenship competencies focused on school context, it provided interesting insights that seemed adaptable to the knitting group workshops. According to this researcher, four principles need to be kept in mind when teaching citizenship competencies, learning by doing, meaningful learning, reflecting, and performance according to the zone of proximal development (ZPD).

First, learning by doing seeks the development of these competencies by putting them into practice. Second, meaningful learning refers to the degree to which the activities are related to students' daily life. Third, reflecting aims at raising awareness about the development of the competencies and facilitates questioning of beliefs. Fourth, performance according to the ZPD reminds us about the importance of the proposed activity [to teach citizenship] being not that easy neither too difficult but challenging for the student.

The following sections provide samples of activities carried out during some workshops, each one illustrates possible ways to introduce content that could contribute to mothers' understanding and application of assertiveness and empathy with their children. Each section addresses and attempts to adapt one of the four principles suggested by Chaux (2008) when it comes to teaching citizenship competencies.

A reflection is written by the researcher under each section to analyze and interpret what happened in each workshop by answering questions like: what happened? How did it happen? Why did it happen? What were the results? What needs to be improved next time? and construct a rationale that could help answer the research questions.

\section{Learning by doing}

This workshop session started by introducing and establishing the difference between telling statements and asking statements. The former refers to typical sentences told by mothers to their children. For example: You must respect your elders, I have told you that you have to greet people, you know that your bedroom must be organized.

Asking statements, on the other hand, seek to provoke reflection on the child. They are useful to provide children with the opportunity to exert an active role to solve a given misbehavior or conflict. Some examples of asking statements are: what happened? What could happen if ...? What could you do to ...? What do you think you could do to repair the harm done? In this activity the mothers were shown two statements on the same topic and were asked to analyze the difference. Next they were asked to classify a good number of statements into two categories, "cantaleta", a colloquial term used in Colombia that means constant nagging and bothersome and repetitive petition; and reflection. In other words, telling statements (cantaleta) and asking statements were categorized. Mothers were also asked to name some of their children's common misdeeds or misbehavior episodes and were asked to 
select the most appropriate asking statements to establish a dialogue where the child could be granted active participation. Mothers could identify easily the statements that meant cantaleta and were surprised at the way they could be changed into asking statements or opportunities for reflection with children.

Rationale

The workshop aimed at providing the mothers with opportunities to transition from declarative knowledge of citizenship competencies which was evident they possessed as shown in the interviews before the workshops, to a possible application based on procedural and attitudinal knowledge in their household which they were not sure how to address except by the acknowledgement that setting the example is key. This relates to the need to move beyond passive learning experiences when addressing citizenship competencies, as research has continuously pointed out (Ministry of Education, 2004; Chaux et al. 2004; Rodriguez, Lopez and Echeverry 2017; Chaux, 2008 as cited in Castillo, 2018).

First, by doing the categorizing exercise mothers were encouraged to be doers and participants instead of just being passive listeners. It means ensuring understanding of the topic by doing something with the information explained by the researcher. Mothers were actively involved in the activity and worked enthusiastically with others.

Second, this session was intended to start helping mothers build empathy with their children by being introduced to telling and asking statements, two concepts originated in the Positive Discipline approach.

Telling statements (You must respect your elders, I have told you that you have to greet people, you know that your bedroom must be organized) imply that children know, in this case, how respect and organization are demonstrated and why they are important. They are said by adults under the assumption that children will understand and use them just by passively listening to such statements.

On the other hand, the asking statements (what happened? What could happen if you keep running around the house? What do you think you could do to repair the harm done?) appear to be useful to build empathy between the mother and the child. This because the child is granted active participation to solve the issue he is involved in and might feel respected and cared for instead of judged for having made a mistake or having misbehaved. The mother in turn, could understand that through such statements she can demonstrate empathy to her child especially when misbehavior has occurred. At the same time this exercise is useful to raise mothers' awareness to use conflict or misbehavior as opportunities to help children develop the abilities and values they want to learn for life. In short, mothers were exposed to tools and activities that could help them learn about empathy and assertiveness by being empathic and assertive with their own children.

Meaningful learning 
The next is the experience of one of the mothers in the knitting group and the steps undertaken in one of the workshop sessions to allow meaningful learning to take place.

Maria and her 7-year-old son argued constantly about him being late for the school bus. JP takes a long time getting ready and Maria, his mom, gets very frustrated because he does not cooperate, and both end up being late and upset.

Procedure during workshop:

First, Maria was asked to restate what she usually told him when this situation occurred. Some statements were: You are going to miss the school bus if you do not hurry up! It is not good to be late! I have told you many times, you have to get up early, you are old enough to understand it!

Second, she was also asked to think about her tone of voice and body language during these episodes. She said she sounded irritated and frustrated and was rude to her son. When asked about her son's attitude she said he did not hurried up and

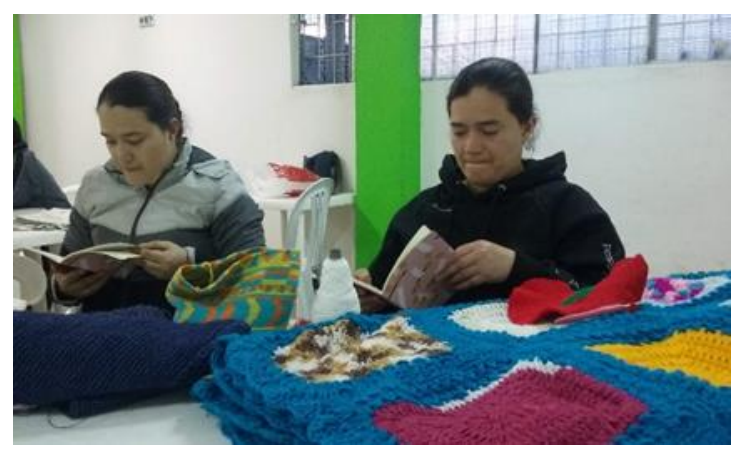
seemed careless about being late.

Next, Maria was asked about the ability she wanted JP to develop in the long term. She said she wanted her son to learn to be punctual and that was why she rushed him to be ready on time. Another mother commented "since an early age we teach children to be punctual so when they have a job, they do not arrive at 10 am to work". The next questions asked by the researcher were how to teach them to be punctual? By telling them to be punctual? By scolding them every time they are late for something? Or by setting the example and creating opportunities for them to be punctual and learn to plan, foresee obstacles, leave earlier? The mothers agreed that the best way was to model punctuality and ways to be punctual. The question that remained was how to set the example when adults are not the best models of punctuality?

Lastly, Maria and the other mothers were asked to formulate asking statements instead to replace the cantaleta. Some examples were: what do you need to do so that your school bag is ready on time in the morning? How do you feel when we are late for the school bus? What do you think we could do to be on time? How would you feel if we were on time? Although the mothers had been previously introduced to the difference between telling and asking statements, further practice needed to be provided.

Rationale 
Although materials such as the manual Educating for Peace (MEN, 2016) and other resources from the internet offer useful guidance and materials to teach citizenship competencies, using real life situations shared by the mothers gave way to a meaningful demonstration of assertiveness and empathy at work.

The purpose of this session was to exemplify, once again, how mothers could start replacing telling statements with asking statements by using a situation, shared by one of the mothers, with her 7-year-old son. As she mentioned, she was frustrated because of her son was not cooperative to catch the school bus on time. She reacted as many of us would, by lecturing (using telling statements) by being frustrated and rude. Unfortunately, the wrong message transmitted to children when we show frustration is that this is the way problems are solved. This clearly sustains what Durrant (2016) says about the tendency of parents working only on fulfilling the short term goals, in this case being on time for the school bus instead of taking advantage of children's mistakes to work on the development of long term abilities like learning how to be punctual in life.

Asking statements used in this case (what do you need to do so that your school bag is ready on time in the morning? How do you feel when we are late for the school bus? What do you think we could do to be on time? How would you feel if we were on time?) reflect a more assertive communication and models empathy. Assertiveness is reflected in the way polite language is used in the questions to the child and in the confidence transmitted to him about expressing his ideas. Empathy is expressed towards the child by taking into consideration thoughts and feelings expressed in his responses to the questions. In this way, not only mothers but fathers can start learning to communicate assertively with the children and start being empathic by creating agreements based on respectful and constructive conversations where their children's needs and views are considered.

\section{Reflecting}

Reflecting as explained by Chaux (2008) seeks to raise awareness about the development of the citizenship competencies and to facilitate questioning beliefs.

A session was devoted to help the participants distinguish between two approaches to discipline issues with children, punishment and consequences. The workshop started by having the mothers classify under these two categories on the board several characteristics written on paper and pasted on the walls. Next, participants were asked how they would define punishment, the type of punishments they had used with their children, and how they felt after having punished their children. Lastly, the difference between punishment and consequence was explained by mentioning different characteristics. Another session was necessary to clarify the same topic by using two case studies and analyzing with the mothers what a punitive approach in these cases would be and what possible consequences could there be to address each of them. Although the mothers participated and seemed to have understood, it was noticeable that they needed more practice to distinguish between punishment and consequence and how to apply them. 


\section{Rationale}

Although mothers were introduced to the difference between punishment and consequence, the workshops could have been more fruitful by encouraging reflection, by helping participants question beliefs. This could have been done by not only asking them to define punishment but also to ask them questions to make them reflect about their own beliefs. For example, do you think your children learn when you punish them? Why? How do you think your child feels when you punish him? What does your body language say to your child when you punish him? Then, by asking questions to check their understanding and application of consequences. For instance, How does knowing about consequences help you address discipline issues with your child? How can consequences be used to demonstrate empathy and assertiveness with your child? Reflection must be inherent part of workshops when new information is presented to participants, in this way they could start questioning beliefs and teaching practices and being more conscious about developing citizenship competencies.

\section{Performance according to the ZPD}

This aspect can be integrated into workshops from the child and mother's perspective. The first one keeping in mind the children and what they can do at certain cognitive developmental stages, for example:

In one of the meetings some mothers agreed that they hardly thought about specific characteristics children demonstrate at different ages and expressed that they usually expect their children to behave appropriately. This is what Gloria, one of the mothers said in this respect in one of the meetings: "We expect that children do and know things the way we do, we treat them as little adults". She also added: "children learn to know us, what we like and what we do not" which might imply that adults assume children know how to behave and understand the reasons behind expected behaviors. To address this topic with the mothers, a session was devoted to clarifying the different cognitive developmental levels children go through. Mothers were explained orally the way children think and feel across different age periods $(0$ to 6 months, 6 to 12 months, 1 to 2, 2 to 3,3 to 5 and 5 to 9 years of age). This appeared to be too much information that distracted and confused some of the participants, as stated by Maria, "sometimes there is a lot of information to remember and keep in mind with our children"

Second, mother's performance should be tailored to their zone of proximal development. This means planning workshops that are not too demanding and could result in frustration, nor too easy that mothers do not feel challenged to learn.

\section{Rationale}

Durrant (2016) in her work of positive discipline in everyday parenting explains that is fundamental for parents and caretakers to understand how children think and feel across different developmental levels. This is because when we as adults see the 
world through the eyes of a toddler, a 5-year-old child or 13-year-old boy or girl, we begin to understand the reasons behind certain behaviors. Only then we can start being empathic and assertive. Only then we can start being better parents or educators. Unfortunately, this understanding was not built as the information about developmental levels was not successfully transmitted. In future workshops, mothers could be in charge of reading about one of these stages and preparing an activity to demonstrate its characteristics or analyzing their own child's developmental stage.

Regarding mothers' performance (ZPD) it was noticeable during some workshops that they struggled understanding and putting into practice concepts such as asking statements, affective questions and types of consequences addressed in Positive Discipline. This implies, on the part of the researcher, the need for a careful revision and adjustments of workshops content and tasks, so that they are tailored to suit the characteristics of the participants.

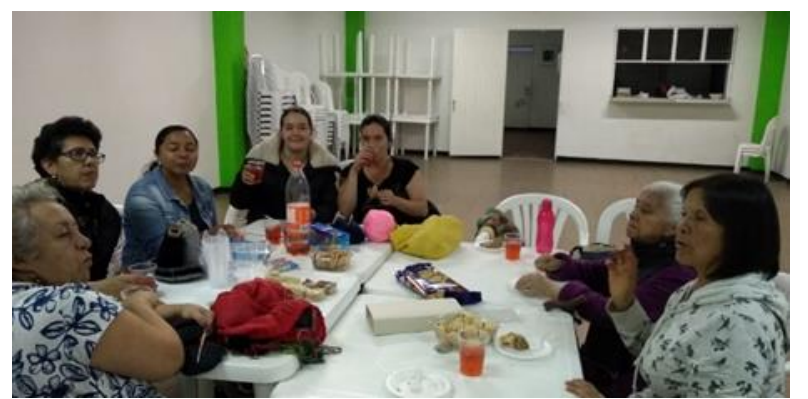

Finally, circles were an unexpected factor that highly contributed to the development of meaningful workshops. Due to the nature of the meetings in which we all were sitting in a circle shape knitting and talking, all the workshop sessions were held in a circular sitting arrangement. The researcher used this dynamic as an opportunity to get close to the participants and to carry out community circles following the principles of restorative practices. The circle protocol advised by the restorative practices is based on questions created to lead participants in the discussion of issues that affect them, this dynamic encourages every single participant to answer such questions.

During one of the meetings, Ana, one of the mothers, shared with the group the difficult relationship she had with an authoritarian husband who constantly disrespected their sons. To address her case, a circle was carried out in order to encourage this mother, and the others, to express her feelings and opinions to her husband. Some of the guiding statements and questions discussed were:

Name 3 of your qualities, what's something that makes you feel happy at home? What's something that makes you feel unhappy at home? How can you solve what makes you unhappy at home?

The questions sparked active and genuine participation on the part of mothers, as a result, the time planned to execute the circle had to be extended because mothers wanted to share their experiences and give advice to Ana. Even though by the end of the circle, she did not really feel encouraged to talk to her husband, a very strong connection among us was felt. We were connected as women, mothers, and wives because we heard each other, we understood each other, saw ourselves reflected in the other, and felt empathy and concern about each other. That day, we wanted to keep talking and to stay longer than usual in a place and time that had become 
ours. Certainly, such bonding did not occur overnight, it was the result of countless, continuous, and meaningful interaction.

\section{Lessons learned from the experience with the community (Findings)}

Helping mothers build citizenship competencies such as assertiveness and empathy with their children is possible through the integration of some elements of restorative practices (i.e., affective questions, affective statements and circles) and positive discipline (i.e., asking statements, consequences, parenting long term goals, stages of cognitive development) into workshops.

A combined methodology that includes workshops developed under four principles: learning by doing, meaningful learning, reflecting and planning performance according to the ZPD; and community circles to discuss participants' perspectives and experiences, can set the ground to address one of today's greatest challenges in the Colombian context, building empathy and assertiveness first at a personal level, but most importantly community wide.

The circle dynamic used during the meetings of the knitting group was the cornerstone of community building. Mothers created bonds with each other by sharing not only a space and activities, but most importantly by sharing their concerns and struggles at home, "When we have these talks, we feel relieved" said Ana. This experience fostered the willingness on the part of mothers to give advice or just listen to others. Unknowingly by giving advice and listening they had started to change, to transform their experience because "transformation is rooted in and sustained through relationships" (Willie, 2000 as cited in Diazgranados et al., 2014). If parents' abilities to teach empathy and assertiveness are to be strengthened, then the community is one of the places for them to start nurturing such abilities in themselves.

Although the meetings allowed sharing experiences and to some extend discussion on how to deal with the teaching of citizenship competencies, there could be still a disconnect between what was discussed in the meetings and what it was actually believed and done by the mothers at home. One reason might be that the workshops failed to encourage participants to question beliefs. Another reason might be that they feel that the agreements reached with their children are a way to give up power and lose authority, as Rose, one of the older mothers expressed, "limits must be imposed to our children otherwise they will ignore our authority". This implies a profound transformation of beliefs about the roles mothers and fathers perform in the family. Further research is required to enquire about the understanding and application of the restorative practices and positive discipline in the home environment and mothers' stance towards new approaches to discipline.

Nonetheless, mothers showed a genuine interest in continue learning about citizenship competencies as stated by Ana, "I need to learn more to grow as a person and as a mother, to have something to teach to my child" and Flor, "I need to reinforce some topics, I feel there are things that I do not do well for example, 
allowing my son to spent too much time playing on the tablet or not allowing him to be independent'. This attitude relates to what Ruiz and Chaux (2005) suggested about kindergarten and the early years of primary education being fertile ground to work with parents, it seems that parents of kindergarteners and early graders are more receptive to the support schools [or the community] provide when their children are small. This age is also optimal for moral education as it is the time when children develop the basic competencies to relate to others. To this end, the programs offered by the Community Action Committee are valuable opportunities to reach out to young parents and families in general.

Mothers in the knitting group acknowledged not only the need for them to learn more about teaching assertiveness and empathy to their children but first and foremost, recognized they need to live such competencies within the family. In Gloria's words "our children take after us, not only physically but our manners and behavior", and Patty's opinion "if one is rude, that's what the child does and repeats". These mothers' willingness to learn and desire to set a good example for their children open a window to the creation of programs on citizenship competencies for the family and a priceless opportunity to transform deep-rooted beliefs and practices that have perpetuated conflict for so long.

As a teacher researcher I am interested in establishing a direct link between the knowledge I have acquired through my academic experience and the needs of a community I belong to. This systematization of experience served to advance my own understanding of citizenship competencies and ways to teach them and has strengthened my desire to continue working and reaching out to the community. In this process I came to the realization that building community must precede any attempt to share expertise with its members. The workshops and community circles are valuable means to promote learning opportunities among the community who usually desires that its children grow up being good citizens. Citizenship competencies must concern not only teachers or parents but, above all, the whole community.

Key factors that might have promoted transformation were:

- The circle dynamic used encouraged the mothers to share difficulties lived at home.

- Mothers' desire for their children to develop citizenship competencies for life.

- The participation of a teacher researcher whose role was facilitating rather than lecturing.

- The learning process lived by the researcher during this systematization experience.

- The BH Community Action Committee participation who offers constant learning opportunities to the community. Thanks to one of these programs, the present study took place.

Some obstacles faced during the project had to do with the short duration of the meetings, some participants' recurrent absences and the lack of experience of the 
researcher in planning workshops addressing citizenship competencies with parents.

Some practical suggestions are presented for parents, caregivers and teachers to start demonstrating and helping children develop assertiveness and empathy.

- Lecturing children about assertiveness and empathy is not enough for them to become assertive and empathic. Adults need to be worthy of children or students' imitation by letting them see how we ourselves communicate assertively and how we demonstrate empathy to others.

- Start by respecting the child's developmental level and do not expect them to behave as mature adults. Instead of judging the child based on the misdeed, use the misdeed to teach abilities for life.

- Use language wisely; insulting, screaming or physical punishment send a wrong message to children about conflict management. Even worse, this might cause long term effects such as alienation and resentment. The first step to help children develop citizenship competencies is for us to become assertive and empathic adults worthy of imitation.

- The principles provided by Chaux (2008) originally designed to teach citizenship competencies to students, can be easily adapted to design workshops for parents so that they replicate practices with their children.

First, workshops need to provide participants with opportunities to learn by doing as opposed to mere lecturing from an expert. The same procedure applies at home where parents should use conflict not to nag but as a learning opportunity where assertiveness and empathy are demonstrated by means of affective and asking statements.

Second, meaningful learning with the mothers must be based on situations lived by them at home and with their children. At home, meaningful learning means taking advantage of actual conflict to put into practice restorative practices and positive discipline.

Third, constant reflection opportunities must be provided so that mothers realize that every conflict can turn into a teachable moment to help children build long life abilities as opposed to short term solutions based on punishment. At home, reflection is promoted using affective questions when misbehavior has occurred.

Finally, performance according to the zone of proximal development (ZPD) must be made possible for the mothers by including activities in the workshop that are not too easy not too challenging for them. With the children it is essential to be knowledgeable about their cognitive developmental level, so 
that adults use statements and encourage actions that are age appropriate and suitable to address given circumstances.

- Circles must be inherent to the workshop methodology since the beginning of a given program because they enable participants to build bonds and confidence.

- When facilitating community circles, they must follow the protocol advised by the Restorative Practices Handbook, this means establishing an objective, and creating questions to guide the discussion based on the objective. The role of the facilitator is not only to ensure that the conversation sticks to the objective of the circle, but also to encourage participation in a way that participants feel heard, understood and connected. 


\section{References}

Barnechea, M. M., \& Morgan, M. D. (2007). Propuesta de método de Sistematización de Experiencias, trabajo de investigación para el Magister en Sociología. Lima: PUC.

Cadena, F. (1985). La sistematización como creación de saber de liberación, programa de apoyo a la sistematización y autoevaluación de la educación popular. Santiago, Chile: Consejo de Educación Popular de América Latina y el Caribe (Ceaal).

Castellanos, M. \& Chaparro, M. P. (2016). Kit PaPaz Familias y Comunidades Educando para La Paz. Organización Internacional para las Migraciones (OIM) - Corporación Colombiana de Padres y Madres (Red PaPaz). Retrieved from: content/uploads/2016/05/Kit RedPaPaz Paz.pdf

http://redpapaz.org/paz/wp-

Castillo, M. (2018). Fortalecer las Competencias Ciudadanas en la Solución de Situaciones Cotidianas (Master's thesis). Retrieved from https://bdigital.uexternado.edu.co/bitstream/001/1082/1/CAA-Spa-2018Fortalecer las competencias ciudadanas en la soluci\%C3\%B3n de situ aciones Cotidianas Trabajo.pdf

Cifuentes, R. M. (1999). La sistematización de la práctica del trabajo social. Retrieved from: http://www.ts.ucr.ac.cr/binarios/pela/pl-000560.pdf

Costello, B., Wachtel, J., \& Wachtel, T. (2009). The Restorative Practices Handbook for Teachers, Disciplinarians and Administrators. Bethlehem, PA 18016 USA: International Institute for Restorative Practices.

Costello, B., Wachtel, J., Wachtel, T. (2010). Restorative circles in Schools. Building Community and Enhancing Learning. International Institute for Restorative Practices. Bethlehem, Pennsylvania, USA.

Chaux, E., Lleras, J. \& Velasquez, A. (2004). Competencias Ciudadanas: De los estándares al Aula. Retrieved from: file:///C:/Users/Gateway/Downloads/CompetenciasciudadanasDelosestanda resalaula.Unapropuestaintegralparatodaslasareasacademicas.pdf

Clifford, A. (2015) Teaching Restorative Practices with Classroom Circles. Center for Restorative Approaches. Retrieved from: http://www.healthiersf.org/RestorativePractices/Resources/documents/RP\% 
20Curriculum\%20and\%20Scripts\%20and\%20PowePoints/Classroom\%20C urriculum/Teaching\%20Restorative\%20Practices\%20in\%20the \%20Classroo m\%207\%20lesson\%20Curriculum.pdf

Creswell, J.W., (2012). Educational Research. Planning, Conducting and Evaluating Quantitative and Qualitative Research. Pearson.

De Souza, J. F. (2008). Sistematización: un instrumento pedagógico en los proyectos de desarrollo sustentable. Revista Internacional Magisterio, 23, 813.

Diazgranados, S., Noonan, J., Brion-Meisels, S., Saldarriaga, L., Daza, B.C., Chávez, M., and Antonellis, I., (2014). Transformative peace education with teachers: lessons from Juegos de Paz in rural Colombia, Journal of Peace Education, DOI: 10.1080/17400201.2014.898627

Durrant, J.E. (2016) Disciplina Positiva en la Crianza Cotidiana. Save the Children Sweden. Retrieved from https://resourcecentre.savethechildren.net/node/7509/pdf/positive discipline in everyday parenting $\mathrm{sp}$ hi-res final 2017.pdf

International Institute for Restorative Practice IIRP (2016). Defining Restorative. Retrieved from https://www.iirp.edu/

Jara, O. (1994). Orientaciones teórico-prácticas para la sistematización de experiencias. Centro de estudios y publicaciones Alforja. Programa latinoamericano de apoyo a la sistematización -CEAAL- Costa Rica.

Jara, O. (2018). La Sistematización de Experiencias: Práctica y Teoría para Otros Mundos Posibles. Fundación Centro Internacional de Educación y Desarrollo Humano CINDE. Retrieved from: https://repository.cinde.org.co/visor/Preview.php?url=/bitstream/handle/20.5 00.11907/2121/Libro\%20sistematizacio\%CC\%81n\%20CindeWeb.pdf? sequence $=1$ \&isAllowed $=y$

Kawulich, B. (2005). Participant Observation as a Data Collection Method [81 paragraphs]. Forum Qualitative Sozialforschung / Forum: Qualitative Social Research, 6(2), Art. 43, retrieved from http://nbnresolving.de/urn:nbn:de:0114-fgs0502430.

Martinic, S. (1987). Elementos metodológicos para la sistematización de proyectos de educación popular. Santiago. Cide.

Ministerio de Educación Nacional (2016). Estándares Básicos de Competencias Ciudadanas. Guía No $6 . \quad$ Retrieved from: https://www.mineducacion.gov.co/1621/articles-75768 archivo pdf.pdf 
Nelsen, J., Lott, L. \& Glenn, S. (4 ${ }^{\text {th }}$ Ed.). (2013) Positive Discipline in the Classroom. Developing Mutual Respect, Cooperation, and Responsibility in Your Classroom. New York: Three Rivers Press.

Rodríguez, A., López, G. \& Echeverry, J. (2017). El aula de paz: familia y escuela en la construcción de una cultura de paz en Colombia. Perseitas, 5(1), pp. 206-223. DOI: http://dx.doi.org/10.21501/23461780.2243

Rodríguez, A., Ruiz, S. \& Guerra, Y. (2007). Competencias Ciudadanas Aplicadas a la Educación. Revista de Planeación y Desarrollo, 1(1), 140-157. Retrieved from https://www.researchgate.net/publication/331586728 CoMPETENCiAS CiU dAdANAS APLiCAdAS A LA EdUCACION EN COLOMBiA

Ruiz, A., and Chaux, E. (2005). La Formación de Competencias Ciudadanas. Asociación de Facultades de Educación ASCOFADE. Retrieved from: https://laasociacion.files.wordpress.com/2015/11/la-formacion-decompetencias-ciudadanas.pdf

UNESCO, (2016). Sistematización de experiencias educativas innovadoras. https://unesdoc.unesco.org/ark:/48223/pf0000247007

Vanstralen, M. L. \& López, L. (2018). Desarrollo de competencias ciudadanas en el postconflicto en Colombia. Retrieved from: http://vinculando.org/sociedadcivil/desarrollo-de-competencias-ciudadanasen-el-postconflicto-en-colombia.html\#vcite 